\title{
IL33 Gene
}

National Cancer Institute

\section{Source}

National Cancer Institute. IL33 Gene. NCI Thesaurus. Code C101774.

This gene plays a role in cytokine signaling. 